PERIODICALS OF ENGINEERING AND NATURAL SCIENCES

Vol. 5 No. 1 (2017) - Special Issue (Recent Topics in Environmental Science)

Available online at: http://pen.ius.edu.ba

\title{
Forecasting Foreign Trade of Bosnia and Herzegovina for Wood and Articles of Wood, Wood Charcoal by Seasonal ARIMA Model
}

\author{
Nadir ERSEN \\ Vocational School, Department of Management and Organization Artvin \\ Çoruh University, Turkey,
}

\author{
İlker AKYÜZ \\ Faculty of Forestry, Department of Forestry Industry Engineering Karadeniz \\ Technical University, Turkey \\ *iakyuz@ktu.edu.tr
}

\begin{abstract}
In this study, it is aimed that the analysis of export and import values of Bosnia and Herzegovina for wood and articles of wood, wood charcoal with seasonal ARIMA model and forecasting of export and import values for next term by the best appropriate seasonal ARIMA model. The data used in this study were obtained from Trade statistics for international business development (TRADEMAP) and monthly data covering the period of January 2007 and December 2015. Augmented Dickey-Fuller test was used for the stationarity test. Temporary model that have smallest values of forecasting accuracy measurement was determined. The appropriateness of the model (whether plot of autocorrelation has white noise) was determined by using the Box-Ljung test. As a result, ARIMA $(3,1,0)(0,1,2)_{12}$ model was found as the best forecasting model for both export and import series. It was estimated that export value of Bosnia and Herzegovina for wood and articles of wood, wood charcoal is approximately 531 million\$, while import value is 160 million\$ in 2020.
\end{abstract}

Keywords: Seasonal ARIMA model; wood and articles of wood; wood charcoal; export; import; forecasting

\section{Introduction}

Export provides to remain in the balance of foreign trade by supply the amount of foreign currency going abroad. In addition, companies are becoming more powerful in global competition by expanding the market network with export and as well negative trend of exports in the future. Export / import that are in a close relationship with GDP, interest rates, inflation, etc. may affect the country's economy. Therefore, the forecasting of accurately value of export/import is very important.

There are many forecasting techniques that including qualitative and quantitative for predicting the future. Quantitative methods are contained in the method of time series analysis [1]. There are many methods for analyzing time series. Box-Jenkins method is one of the most used methods. This method is called as ARIMA (autoregressive integrated moving average) analysis. ARIMA model is divided into two. These are nonseasonal and seasonal ARIMA models. ARIMA model combine differencing with autoregression (AR) and a moving average (MA) models. This model can be expressed as $\mathrm{w}_{\mathrm{t}}=\mathrm{c}+\phi_{1} \mathrm{w}_{\mathrm{t}-1}+\ldots \ldots+\phi_{\mathrm{p}} \mathrm{w}_{\mathrm{t}-\mathrm{p}}+\theta_{1} \varepsilon_{\mathrm{t}-1}+\ldots+\theta_{\mathrm{q}} \varepsilon_{\mathrm{t}-}$ ${ }_{q}+\varepsilon_{t}$. Here, $w_{t}$ is the differenced series, $p$ is order of the autoregressive part and $\mathrm{q}$ is order of moving average part. Also, we said this an ARIMA (p,d,q), where, $d$ is a degree of difference [2]. General process of ARIMA model is as follows [2];

1. Plot the data. Identify unusual obversations.

2. If necesarry, transform the data to stabilize the variance.

3. If the data are non-stationary, take first difference the data until the data are stationary.

4. Plot the autocorrelation function (ACF)/partial autocorrelation function (PACF) of the differenced data and try to determine possible candidate models.

5. Try your chosen model(s) and use the akaike information criterion (AIC) to search for better model.

6. Check the residuals from your chosen model by plotting the ACF of the residuals and doing a Ljung-Box test of the residuals. If model has not white noise, determine model again.

7. If model has white noise, calculate forecasts.

ARIMA model was applied many studies $[3,4,5,6,7$, $8,9,10,11,12,13,14,15,16,17,18,19]$. In this study, it is aimed that the analysis export and import values of Bosnia and Herzegovina for wood and articles of wood with SARIMA model. In addition, the best appropriate SARIMA model estimated export and import values. 


\section{Materials and Method}

\subsection{Material}

In this study, it was used that export and import values of Bosnia and Herzegovina for wood and articles of wood, wood charcoal. The monthly data was used for examine the seasonal and trend components. This data covers the period of January 2007 and December 2015. Data were obtained from Trade statistics for international business development [20]. Data was taken as $\$ 1000$. Minitab 16 was used for determine the best model while Eviews- 8 was used for the analysis of stationary.

\subsection{Method}

\subsubsection{Seasonal ARIMA model}

The seasonal ARIMA (SARIMA) model is similar to the ARIMA model which known as a linear approximation for predicting future. This model consists of stages such as identification, estimation, diagnostic checking and forecasting. Accurate predictive models can improve with this model by removing the characteristics of seasonal variation through seasonal differences [21].

The SARIMA model consists of seasonal autoregressive term $(\mathrm{P})$, seasonal integrated term (D), and seasonal moving average term $(\mathrm{Q})$ as well as autoregressive term (p), integrated term (d), and moving average term (q). Generally, the SARIMA model represents as SARIMA $(p, d, q)(P, D, Q)$ and is expressed by equations in follow

$\varphi_{\mathrm{p}}(\mathrm{B}) \Phi_{\mathrm{p}}\left(\mathrm{B}^{\mathrm{S}}\right)(1-\mathrm{B})^{\mathrm{d}}\left(1-\mathrm{B}^{\mathrm{S}}\right)^{\mathrm{D}} \mathrm{y}_{\mathrm{t}}=\delta+\theta_{\mathrm{q}}(\mathrm{B}) \Theta_{\mathrm{Q}}\left(\mathrm{B}^{\mathrm{S}}\right) \alpha_{\mathrm{t}}$

$\varphi_{\mathrm{p}}(\mathrm{B})=1-\varphi_{1} \mathrm{~B}-\varphi_{2} \mathrm{~B}^{2}-\ldots-\varphi_{\mathrm{p}} \mathrm{B}^{\mathrm{p}}$

$\theta_{q}(B)=1-\theta_{1} B-\theta_{2} B^{2}-\ldots-\theta_{q} B^{q}$

$\Phi_{\mathrm{p}}\left(\mathrm{B}^{\mathrm{S}}\right)=1-\Phi_{\mathrm{S}} \mathrm{B}^{\mathrm{S}}-\Phi_{2 \mathrm{~S}} \mathrm{~B}^{2 \mathrm{~S}}-\ldots-\Phi_{\mathrm{PS}} \mathrm{B}^{\mathrm{PS}}$

$\Theta_{\mathrm{Q}}\left(\mathrm{B}^{\mathrm{S}}\right)=1-\Theta_{\mathrm{S}} \mathrm{B}^{\mathrm{S}}-\Theta_{2 S} \mathrm{~B}^{2 \mathrm{~S}}-\breve{\mathrm{g}}-\Theta_{\mathrm{QS}} \mathrm{B}^{\mathrm{QS}}$

Here, $y_{t}$ is the observation value at time $t, \alpha_{t}$ is the lagged error at time $\mathrm{t}, \mathrm{B}$ is the lag operator defined by $\mathrm{B}_{\mathrm{k}} \mathrm{y}_{\mathrm{t}}=\mathrm{y}_{\mathrm{t}-\mathrm{k}} ; \quad \varphi_{\mathrm{p}} \quad(\mathrm{p}=1,2, \ldots \mathrm{p}), \quad \Phi_{\mathrm{P}} \quad(\mathrm{P}=1,2, \ldots, \mathrm{P}), \quad \theta_{\mathrm{q}}$ $(\mathrm{q}=1,2, . . \mathrm{q})$ and $\Theta_{\mathrm{Q}}(\mathrm{Q}=1,2, \ldots \mathrm{Q}), \mathrm{p}$ and $\mathrm{q}$ are the order of non-seasonal autoregressive and non-seasonal moving average, $\mathrm{P}$ and $\mathrm{Q}$ is the order of seasonal autoregressive and seasonal moving average, $d$ is order of regular difference, $\mathrm{D}$ is order of seasonal difference and $\mathrm{S}$ is a seasonal length [21, 22].

\subsubsection{Forecasting Accuracy Measurements}

For the series, forecasting values are calculated and compared with the actual values of the series. There are several criteria for forecasting accuracy measurement. Forecasting accuracy measurements used in this study were given as follows:

Mean Absolute Percentage Error;

$(\mathrm{MAPE})=\sum\left|\frac{\check{y}_{t}-y_{t}}{y_{t}}\right| \frac{100}{n}$

Mean Square Error $(\mathrm{MSE})=\frac{\sum\left(\check{y}_{t}-y_{t}\right)^{2}}{n}$

Here, $\check{y}_{t}$ is the forecasting value of model, $y_{t}$ is the actual value of model and $\mathrm{n}$ is the number of observations [19, 23]. The criteria of MAPE for model evaluation were in Table 1.

Table 1. MAPE values for model evaluation [24]

\begin{tabular}{ll}
\hline MAPE $(\%)$ & Evaluation \\
\hline MAPE $\leq 10 \%$ & High accuracy forecasting \\
\hline $10 \%<$ MAPE $\leq 20 \%$ & Good forecasting \\
\hline $20 \%<$ MAPE $\leq 50 \%$ & Reasonable forecasting \\
\hline MAPE $>50 \%$ & Inaccurate forecasting \\
\hline
\end{tabular}

\section{Results}

Firstly, it must be provided to export and import series of stationary condition. For this, the stationary of export and import series were analyzed with Augmented Dickey-Fuller (ADF) unit root test and results shown in Table 2. It was seen that series is stationary in the 5\% significance level according to ADF test when taken difference of the natural logarithm series. The 1 stdifference of series was taken. Distribution graph of natural logarithm and differenced of export and import series were shown in Figure 1 and 2.

Table 2.Augmented Dickey-Fuller (ADF) test results

\begin{tabular}{ccccc}
\hline \multirow{2}{*}{ Export series } & $\begin{array}{c}\text { Augmented Dickey- } \\
\text { Fuller test statistic }\end{array}$ & $-0,075962$ & 0,245091 & $-2,867914$ \\
\hline \multirow{2}{*}{ Import series } & $\begin{array}{c}\text { Augmented Dickey- } \\
\text { Fuller test statistic }\end{array}$ & $-0,376831$ & $-0,108246$ & $-2,645649$ \\
\hline \multirow{2}{*}{$\begin{array}{c}\text { Test critical } \\
\text { values }\end{array}$} & $1 \%$ Level & $-2,589531$ & $-2,589531$ & $-2,589531$ \\
\cline { 2 - 5 } & $5 \%$ Level & $-1,944248$ & $-1,944248$ & $-1,944248$ \\
\hline
\end{tabular}




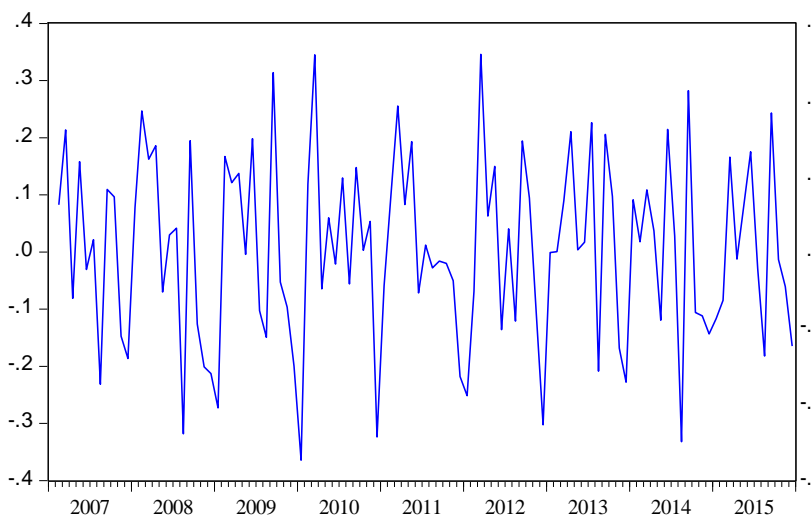

Figure 1.Stationarized export series of graphics

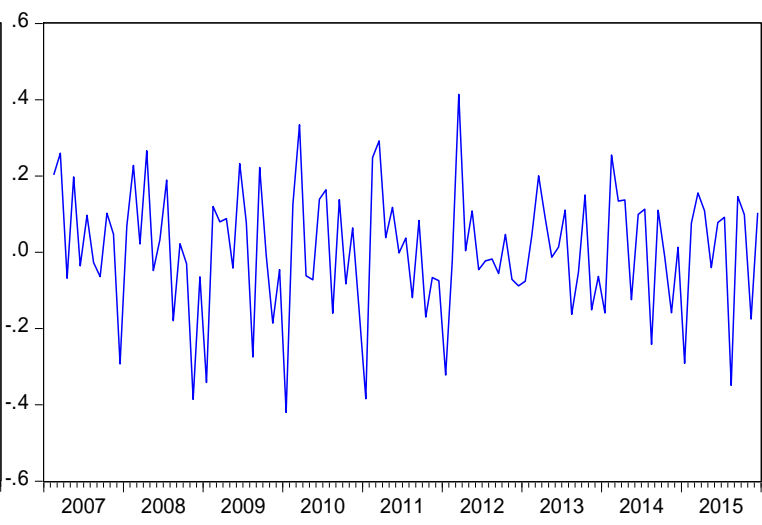

Figure 2.Stationarized import series of graphics
According to Figure 1 and 2, the mean and variance of export and import series are a constant. But, series comprise seasonality. For this, natural logarithm and differenced of export and import series were taken seasonal difference (12st difference). After obtaining these series of stationary conditions, a variety of
ARIMA $(p, d, q)(P, D, Q)_{12}$ models has been tested by autocorrelation and partial autocorrelation graphics of the export and import series. Autocorrelation and partial autocorrelation graphics of stationarized these series were shown in Figure 3, 4, 5 and 6.

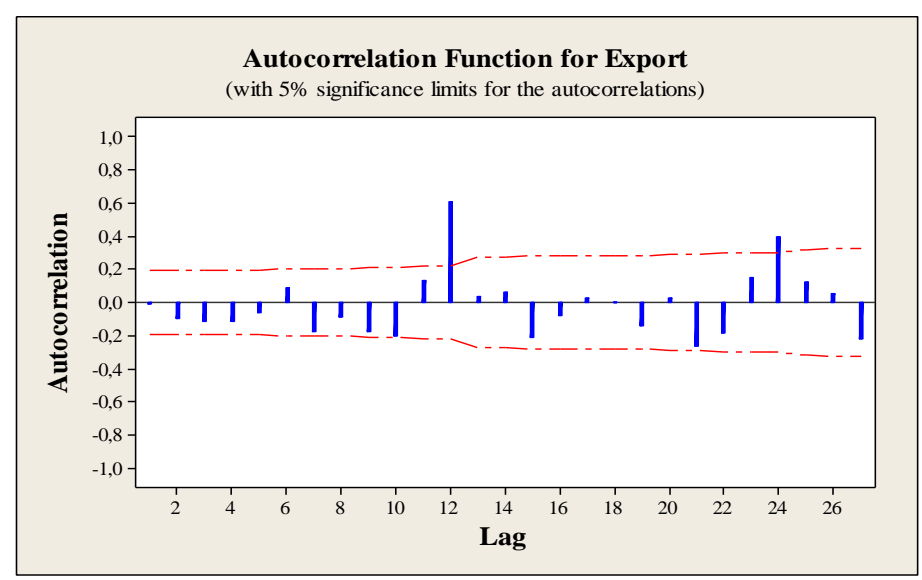

Figure 3. Autocorrelation graphic of stationarized export series

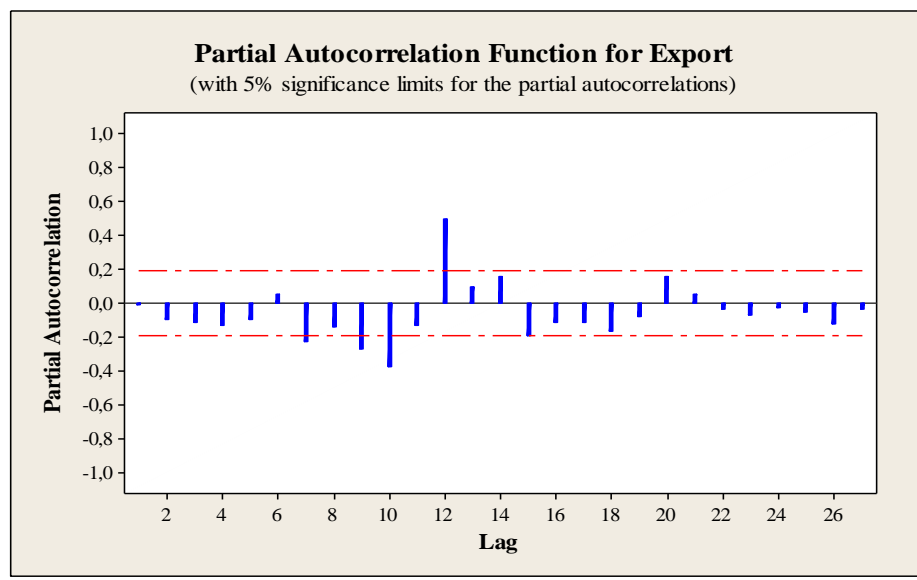

Figure 4. Partial autocorrelation graphic of stationarized export series 


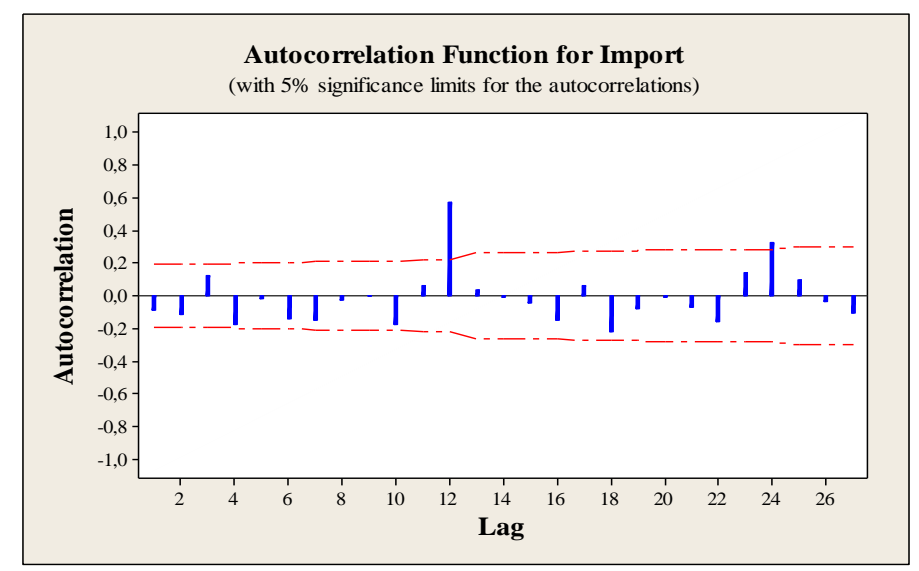

Figure 5. Autocorrelation graphic of stationarized import series

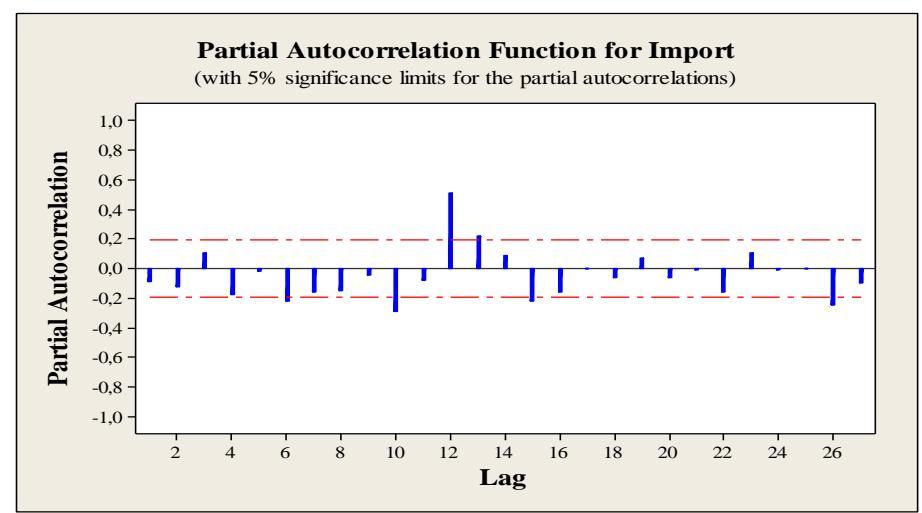

Figure 6. Partial autocorrelation graphic of stationarized import series

As a test results, ARIMA $(3,1,0)(0,1,2)_{12}$ model which have smallest values of the error sum of squares (SSE) and the mean square error (MSE) was determined as temporary model for both export and import values of Bosnia and Herzegovina for wood and articles of wood, wood charcoal. The results related to the model were given in Table 3 and 4 . The suitability of models were tested with Ljung-Box Q statistic and results shown in Table 5 and 6.

Table 3.Analysis results of ARIMA $(3,1,0)(0,1,2)_{12}$ model for export

\begin{tabular}{lccc}
\hline Variable & Coefficient & Std. Error & t-Statistic \\
\hline $\operatorname{AR}(1)$ & $-0,251$ & 0,1023 & $-2,45$ \\
\hline $\operatorname{AR}(2)$ & $-0,074$ & 0,107 & $-0,69$ \\
\hline $\operatorname{AR}(3)$ & 0,2464 & 0,1022 & 2,41 \\
\hline SMA(12) & 0,5397 & 0,1066 & 5,06 \\
\hline SMA(24) & 0,3528 & 0,1116 & 3,16 \\
\hline Number of observations & 108 \\
\hline After differencing & 95 \\
\hline The error sum of squares & 0,945841 \\
\hline The mean square error & 0,010509 \\
\hline
\end{tabular}

Table 4.Analysis results of ARIMA(3,1,0)(0,1,2) ${ }_{12}$ model for import

\begin{tabular}{lccc}
\hline Variable & Coefficient & Std. Error & t-Statistic \\
\hline $\operatorname{AR}(1)$ & $-0,3234$ & 0,1019 & $-3,17$ \\
\hline $\operatorname{AR}(2)$ & $-0,0659$ & 0,1072 & $-0,61$ \\
\hline $\operatorname{AR}(3)$ & 0,2847 & 0,0998 & 2,85 \\
\hline SMA(12) & 0,422 & 0,1098 & 3,84 \\
\hline SMA(24) & 0,4456 & 0,1134 & 3,93 \\
\hline Number of observations & \multicolumn{3}{c}{108} \\
\hline After differencing & 95 \\
\hline The error sum of squares & \multicolumn{3}{c}{0,845125} \\
\hline The mean square error & 0,00939 \\
\hline
\end{tabular}


Table 5.The $Q_{L B}$ statistic and $X^{2}$ values of ARIMA $(3,1,0)(0,1,2)_{12}$ model residuals in different lags for export

\begin{tabular}{|c|c|c|c|}
\hline Lags & $\mathrm{Q}_{\text {statistic }}$ & $X_{\text {table }}^{2}(\alpha=0.05)$ & Degree of freedom \\
\hline 12 & 13.9 & 14.07 & 7 \\
\hline 24 & 27.6 & 30.14 & 19 \\
\hline 36 & 36.9 & 43.77 & $31 \approx 30$ \\
\hline 48 & 52.3 & 55.76 & $43 \approx 40$ \\
\hline
\end{tabular}

Table 6.The $Q_{L B}$ statistic and $X^{2}$ values of ARIMA $(3,1,0)(0,1,2)_{12}$ model residuals in different lags for import

\begin{tabular}{lrrc}
\hline Lags & $\mathrm{Q}_{\text {statistic }}$ & $X_{\text {table }}^{2}(\alpha=0.05)$ & Degree of freedom \\
\hline 12 & 12.8 & 14.07 & 7 \\
\hline 24 & 19.9 & 30.14 & 19 \\
\hline 36 & 28.6 & 43.77 & $31 \approx 30$ \\
\hline 48 & 44.8 & 55.76 & $43 \approx 40$ \\
\hline
\end{tabular}

While the actual and forecasting export values for wood and articles of wood, wood charcoal were shown in Figure 7, actual and forecasting export values in
Figure8. In addition, the forecasting values for export and import were given in Table 7 and 8 .

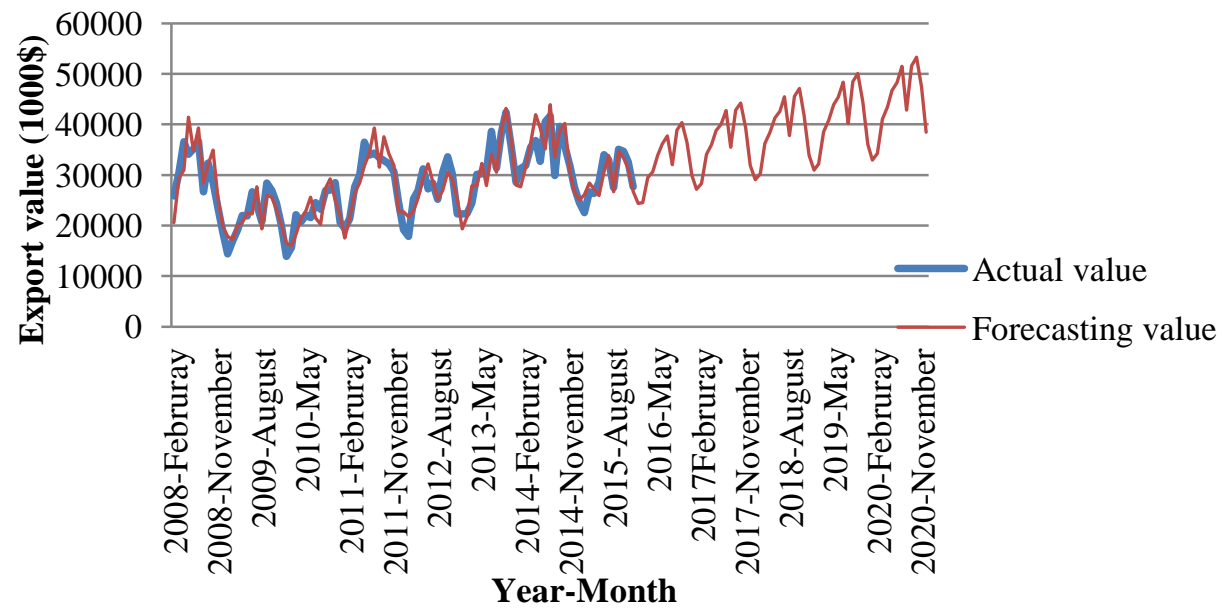

Figure 7. Actual and forecasting values for export (2008-2020)

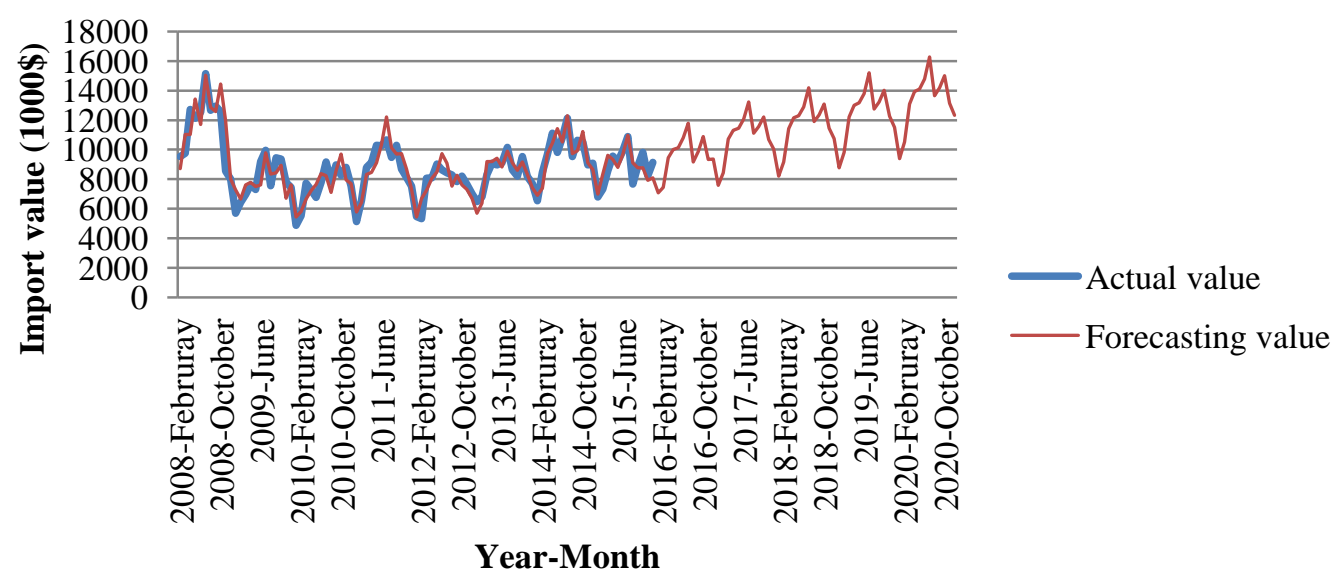

Figure 8. Actual and forecasting values for import (2008-2020)

Table 7.The forecasting values for export in 2016-2020 (1000\$)

\begin{tabular}{|l|c|c|c|c|c|}
\hline Months & $\mathbf{2 0 1 6}$ & $\mathbf{2 0 1 7}$ & $\mathbf{2 0 1 8}$ & $\mathbf{2 0 1 9}$ & $\mathbf{2 0 2 0}$ \\
\hline January & 24404 & 27161 & 29070 & 30935 & 32919 \\
\hline Februray & 24570 & 28367 & 30222 & 32160 & 34222 \\
\hline March & 29440 & 34061 & 36248 & 38572 & 41046 \\
\hline April & 30604 & 35988 & 38346 & 40805 & 43422 \\
\hline
\end{tabular}




\begin{tabular}{|l|l|l|l|l|l|}
\hline May & 33925 & 38751 & 41234 & 43878 & 46691 \\
\hline June & 36141 & 40055 & 42621 & 45354 & 48262 \\
\hline July & 37683 & 42714 & 45469 & 48384 & 51487 \\
\hline August & 32024 & 35528 & 37803 & 40227 & 42807 \\
\hline September & 38846 & 42786 & 45529 & 48449 & 51555 \\
\hline October & 40333 & 44238 & 47079 & 50098 & 53311 \\
\hline November & 36483 & 39281 & 41798 & 44478 & 47331 \\
\hline December & 29865 & 31885 & 33930 & 36106 & 38421 \\
\hline
\end{tabular}

Table 8.The forecasting values for import in 2016-2020 (1000\$)

\begin{tabular}{|l|c|c|c|c|c|}
\hline Months & $\mathbf{2 0 1 6}$ & $\mathbf{2 0 1 7}$ & $\mathbf{2 0 1 8}$ & $\mathbf{2 0 1 9}$ & $\mathbf{2 0 2 0}$ \\
\hline January & 7092 & 7587 & 8196 & 8779 & 9400 \\
\hline Februray & 7442 & 8428 & 9171 & 9818 & 10513 \\
\hline March & 9453 & 10716 & 11409 & 12215 & 13078 \\
\hline April & 10007 & 11311 & 12151 & 13012 & 13932 \\
\hline May & 10137 & 11441 & 12298 & 13167 & 14098 \\
\hline June & 10802 & 12068 & 12882 & 13792 & 14768 \\
\hline July & 11780 & 13237 & 14197 & 15202 & 16277 \\
\hline August & 9177 & 11113 & 11908 & 12750 & 13652 \\
\hline September & 9876 & 11559 & 12362 & 13236 & 14172 \\
\hline October & 10875 & 12211 & 13085 & 14011 & 15002 \\
\hline November & 9342 & 10695 & 11452 & 12262 & 13129 \\
\hline December & 9365 & 10033 & 10738 & 11498 & 12311 \\
\hline
\end{tabular}

\section{Conclusions}

The export and import values of Bosnia and Herzegovina for wood and articles of wood, wood charcoal with seasonal ARIMA model were estimated with seasonal ARIMA model. The natural logarithm, regular difference and seasonal difference of the series were taken. ACF and PACF graphics of the series for determine the appropriate models were examined. Q statistics were calculated for the appropriateness of the model. ARIMA $(3,1,0)(0,1,2)_{12}$ model was found as the best forecasting model for both export and import series. It was found that MAPE value of model for export is $8.12 \%$, while MAPE value for import is $7.54 \%$. It was estimated that export value of Bosnia and Herzegovina for wood and articles of wood, wood charcoal is approximately 531 million $\$$, while import value is 160 million\$ in 2020.

\section{References}

[1] Can M. "Forecasting with time series analysis in business", Phd Thesis, İstanbul University, Social Science Institute, Istanbul, Turkey, 2009.

[2] Hyndman, RJ, Athanasopoulos, G. "Forecasting: principles and practice", OTexts Publisher, 2014.

[3] Çevik O, Yürekli K. "Modeling of Yeşilırmak river's monthly flow series using seasonal ARIMA model",Journal of Agricultural Science, 9(3): 261-268, 2003.

[4] Ismail ZH, Mahpol KA."SARIMA model for forecasting Malaysian electricity generated", MATEMATIKA, 21(2): 143-152, 2005.
[5] Iqubal N, Bakhsh K, Maqbool A, Ahmad AS. "Use of the ARIMA model for forecasting wheat area and production in Pakistan", Journal of Agriculture \& Social Science, 1(2): 120-122, 2005.

[6] Hsiao JM, Shieh CJ. "Evaluating the value of information sharing in a supply chain using an ARIMA model", Int J AdvManufTechnol, 27: 604-609, 2006.

[7] Altın A. "Modeling of water amount which goes into Dodurga dam by using Box-Jenkins technique", Eng\&Arch. Fac. Eskişehir Osmangazi University, XX(1): 81-100, 2007.

[8] Akınc1 M. "Stationary analysis in time series and an application on share in GNP of export", MSc. Thesis, Kafkas University Social Sciences Institute, Kars, Turkey, 2008.

[9] Nanthakumar L, Ibrahim Y. "Forecasting international tourism demand in Malaysia using BoxJenkins SARIMA application", South Asian Journal of Tourism and Heritage, 3(2): 50-60, 2010.

[10] Emang D, Shitan M, Ghani ANA, Noor MK. "Forecasting with univariate time series models: a case of export demand for peninsular Malaysia's moulding and chipboard", Journal of Sustainable Development, 3(3): 157-161, 2010.

[11] Martinez EZ, da Silva EAS, Fabbro ALD. "A SARIMA forecasting model to predict the number of cases of dengue in campinas", State of São Paulo, Brazil, Revista da Sociedade Brasileira de Medicina Tropical, 44(4): 436-440, 2011. 
[12] Polat Ö, Ersungur ŞM."Forecasting foreign trade of Turkey", Journal of Business Economics and Political Science, 1(1): 83-95, 2012.

[13] Karaman E, Firat MZ. Modeling the test day milk yields via time series method. Journal of Kafkas University Veterinary Faculty 2013; 19(4): 659-664.

[14] Özer OO, İlkdoğan U. "The world cotton price forecasting by using Box-Jenkins model", Journal of Tekirdă̆ Agricultural Faculty, 10(2): 13-20, 2013.

[15] Osarumwense OI. "Applicability of Box-Jenkins SARIMA model in rainfall forecasting: a case study of port-harcourt south south Nigeria", Canadian Journal on Computing in Mathematics, Natural Sciences, Engineering and Medicine, 4(1): 1-4, 2013.

[16] Contreras J, Espinola R, Nogales FJ, Conejo AJ."ARIMA models to predict next-day electricity prices", IEEE Transactions on Power System, 18(3): 1014-1020, 2003.

[17] Demir A, Özmen Ö, Rashid A. "An estimation of Turkey's export loss to Iraq", Procedia-Social and Behavioral Sciences, 150: 1240-1247, 2014.

[18] Gikungu SW, Waititu AG, Kihoro JM. "Forecasting inflation rate in Kenya using SARIMA model", American Journal of Theoretical and Applied Statistics, 4(1): 15-18, 2015.
[19] Chang YW, Liao MY.A "Seasonal ARIMA model of tourism forecasting: the case of Taiwan",Asia Pacific journal of Tourism Research, 15(2): 215-221, 2015.

[20] TradeStatisticsfor International Business Development, List 2015 of ExportersandImportersfortheSelectedProducts 44.(http://www.trademap. org/Country_SelProductCountry_TS.aspx 20 Mayıs 2016).

[21] Jeong K, Koo C,Hong T. "An estimation model for determining the annual energy cost budget in educational facilities using SARIMA (seasonal autoregressive integrated moving average) and ANN (artificial neural network)", Energy, 71: 71-79, 2014.

[22] Pao HT. "Forecast of electricity consumption and economic growth in Taiwan by state space modeling", Energy, 34: 1779-1791, 2009.

[23] Göktaş Ö. “Theoretical and applied time series analysi”,". Beşir Publishing, İstanbul, Turkey, 2005.

[24] Lewis CD. "Industrial and business forecasting methods", Published by Butterworths, London, 1982. 